\title{
Early Root and Shoot Elongation of Selected Warm-season Perennial Grasses
}

\author{
JOHN ROGER SIMANTON AND GILBERT L. JORDAN
}

\section{Abstract}

Root length and root:shoot ratios are considered to be important survival factors of seedlings growing in areas of limited water. This study was conducted to determine early root elongation and root:shoot ratios during the germination to seedling stage of 'Premier' sideoats grama [Bouteloua curtipendula (Michx.) Torr.], 'Cochise' lovegrass (Eragrostis lehmanniana Nees $\times$ Eragrostis trichophora Coss and Dur.), 'A-130' blue panic (Panicum antidotale Retz.), and accessions PMT-1733-77 and NM-184 alkali sacaton (Sporobolus airoides Torr.). Root and shoot measurements were made approximately every $12 \mathrm{hr}$ from seed planting to $190 \mathrm{hr}$ and the results related to species success or failure in reported seeding trials. Sideoats grama root lengths were greater than those of all other species at all sample times. Root lengths among the other species were not different until about 5 days after planting when Cochise lovegrass root lengths were significantly $(P<0.05)$ less. Though there was no significant $(P<0.05)$ difference in root lengths among accessions of alkali sacaton, accession 1733 root elongation continued after accession NM-184 root elongation ceased. Sideoats grama shoot lengths were significantly $(P<0.05)$ greater than those of all species until day 6 , when sideoats grama and blue panic were not different. Average 7-day root:shoot ratios ranged from 2.9:1 for sideoats grama to 1.3:1 for blue panic. Rapid root elongation or comparatively high rootshoot ratios obtained for species in this study could not be directly related to reported success or failure in seedling establishment.

Root length and root:shoot ratios are considered important survival and environmental adaptations of plants (Troughton 1956). Perhaps the most critical period of a plant's life is the germination to early seedling stage (7 days) when moisture uptake is dependent on the seminal root (Mueller and Weaver 1942, Tapia and Schmutz 1971). In semiarid and arid climates, characterized by brief periods of soil moisture that are subjected to high potential evaporation rates, water potential in the surface $10 \mathrm{~cm}$ of soil is not maintained above -15 bars for extended periods in the summer (Noy-Meir 1973). Within only a few hours or days of germination. rapid seedling root elongation into relatively moist subsurface soil is a prerequisite to successful establishment (Tadmor and Cohen 1968). In arid and semiarid climates, seedling shoots are exposed to extremely dry air conditions while the seedling roots can be exposed to relatively moister soil conditions. Because high transpiration rates are associated with dry, hot air conditions, a seedling with a relatively large root:shoot ratio should experience less moisture stress (Wilson et al. 1976).

A limited number of studies have indicated species differences in root elongation rates. Wilson and Briske (1979) found that seminal root elongation rates of blue grama [Bouteloua gracilis (H.B.K.) Lag. ex. Griffiths] ranged from 6 to $10 \mathrm{~mm}$ per day. Sosebee and Herbel (1969) reported that 21 days after planting, sideoats grama [Bouteloua curtipendula (Michx.) Torr.] had an average root length of $96 \mathrm{~mm}$ and alkali sacaton (Sporobolus airoides Torr.) had an average length of $38 \mathrm{~mm}$. However, no significant root:shoot ratio (by weight) difference existed between the 2 species. Dalrymple and Dwyer (1967) reported that root:shoot ratios

\footnotetext{
Authors are hydrologist, USDA-ARS, Southwest Rangeland Watershed Research Center, 2000 East Allen Road, Tucson, Ariz. 85719; and professor, Range Management Department, School of Renewable Natural Resources, University of Arizona, Tucson 85721.

Manuscript accepted 13 May 1985
}

(weight based) of sideoats grama decreased from 8:1 for 3-week old plants to 4.9:1 for 15-week old plants and that, as plant age increased, variation in root and shoot weights among species increased. These previous studies indicated species differences in root elongation and root:shoot ratios, but the results may not be comparable because the studies were conducted under various environmental conditions. Also, the critical period of germination to early seedling stage ( 7 days) was not extensively monitored.

The objectives of this study were: (1) to quantify root and shoot elongation and root:shoot ratios of several warm-season perennial range grass species during the germination to early seedling stage ( 7 days), and (2) to relate root elongation and root:shoot ratios to reported success and failures in seedling establishment trials.

\section{Materials and Methods}

Root and shoot lengths of 5 range grasses were determined at 12-hour intervals from seed germination to early seedling stage (7 days). The experimental design was completely randomized with 3 replications of 200 root and shoot observations for each grass. The experiment was conducted over a period of 5 months. Replications occurred randomly over time with all other conditions similar. Germination data were collected to indicate when to begin measurement of root and shoot lengths and to assist in interpretation of root and shoot length data.

Grass species studied were 'Premier' sideoats grama, 'Cochise' lovegrass (Eragrostis lehmanniana Nees $\times$ Eragrostis trichophora Coss and Dur.), 'A-130' blue panicgrass (Panicum antidotale Retz.), and accessions PMT-1733-77 and NM-184 alkali sacaton. These species have been used, with varying success, in many reseeding programs in the southwestern United States (Tromble 1974, Jordan 1981, Cox and Jordan 1983). The study was conducted in a light and temperature controlled growth chamber with alternating temperatures of 30 and $22^{\circ} \mathrm{C}\left( \pm 2^{\circ} \mathrm{C}\right)$ and relative humidity near $100 \%$. High temperatures coincided with $14 \mathrm{hr}$ of light and low temperatures with $10 \mathrm{hr}$ of darkness. Light was supplied by both fluorescent and incandescent lamps that produced 35,300 lumens $/ \mathrm{m}^{2}$. These temperatures and light-dark sequences were similar to reported optima for germination and seedling growth of the species studied (Knipe 1967, Sosebee and Herbel 1969).

Seedlings were grown in cylinders made from $150-\mathrm{mm}$ lengths of 25 -mm diam polyvinylchloride pipe cut in half longitudinally. The 2 halves were held together with rubber bands to form a cylinder open at both ends. One hundred cylinders were placed upright in a holding tray and each filled to within $5 \mathrm{~mm}$ of its top with $135 \mathrm{~g}$ of 20 -mesh, white, crystal silica. Silica was used to minimize variability in soil nutrient content, texture, and bulk density. One seed was placed in each half of the silica-filled cylinder, covered with $5 \mathrm{~mm}$ of silica, and watered with $15 \mathrm{ml}$ of distilled water to bring the silica to field capacity. This initial watering was considered time zero for all subsequent measurements.

Seed germination for each replication was determined for each species using petri dish germination techniques. For each replication, 100 seeds were placed on Whatman No. 2 filter paper, watered with distilled water at time zero, and placed next to the root cylinder holding tray in the growth chamber. Germination counts were made every 12 hours ( $\pm 2 \mathrm{hr}$ ) after initial watering. A seed was considered germinated when its radicle or plumule length was greater than or equal to the seed length. 
Root and shoot length measurements were begun 12 hours after germination was first observed in the germination study and then every 12 hours ( $\pm 2 \mathrm{hr}$ ). At each measurement time, 10 cylinders were randomly taken from the holding tray for observation and measurement and $10 \mathrm{ml}$ of water were applied to each remaining cylinder. Each of the 10 cylinders was separated and the seed from each half observed for germination. If the seed had germinated, its root and shoot lengths were measured to the nearest millimeter. If the seed had not germinated, it was placed in a petri dish with numbered areas on filter paper for later identification and determination of viability. If the identified seed germinated during the remainder of the replication sampling period, the seed was considered viable and zero root and shoot lengths would be recorded for the seed at its originally sampled time. If the seed did not germinate during the replication sampling period, the seed was considered nonviable and not included as a sample for its original sample time.

Analysis of variance and the Scheffe test (Snedecor and Cochran 1980) were used to test hypotheses of root and shoot length differences at common sample times among replication and species means at $P<0.05$. Root:shoot ratios were determined using only nonzero values.

\section{Results and Discussion}

Analysis of variance indicated no significant $(P<0.05)$ differences among replications, so data were combined for analysis of variance among species. Sample times selected for root or shoot comparisons among species represent a range of \pm 2 hours from times listed in the tables or figures. This range was necessary because of deviations in the planned 12-hour sampling schedule. A range less than \pm 2 hours would have eliminated too many comparisons.

\section{Root Lengths}

Sideoats grama had significantly $(P<0.05)$ longer mean root lengths than the other species (Table 1). Mean root lengths among

Table 1. Mean root lengths of species for selected sample times.*

\begin{tabular}{lccccc}
\hline \hline & $\begin{array}{c}\text { Alkali } \\
\text { Cochise }\end{array}$ & $\begin{array}{c}\text { Sacaton } \\
\text { Lime (hr) }\end{array}$ & $\begin{array}{c}\text { Alkali } \\
\text { Panic }\end{array}$ & $\begin{array}{c}\text { Sacaton } \\
1733\end{array}$ & $\begin{array}{c}\text { Sideoats } \\
\text { Grama }\end{array}$ \\
\hline & & & & & \\
58 & $2.5 \mathrm{a}$ & $3.9 \mathrm{a}$ & $4.4 \mathrm{a}$ & $1.6 \mathrm{a}$ & $25.4 \mathrm{~b}$ \\
70 & $6.2 \mathrm{a}$ & $7.2 \mathrm{a}$ & $6.2 \mathrm{a}$ & $5.1 \mathrm{a}$ & $30.6 \mathrm{~b}$ \\
80 & $10.5 \mathrm{a}$ & $12.1 \mathrm{a}$ & $9.6 \mathrm{a}$ & $9.4 \mathrm{a}$ & $39.4 \mathrm{~b}$ \\
92 & $13.8 \mathrm{a}$ & $14.8 \mathrm{a}$ & $12.5 \mathrm{a}$ & $16.7 \mathrm{a}$ & $44.4 \mathrm{~b}$ \\
105 & $15.0 \mathrm{a}$ & $19.3 \mathrm{a}$ & $15.6 \mathrm{a}$ & - & $48.9 \mathrm{~b}$ \\
117 & $15.9 \mathrm{a}$ & $19.5 \mathrm{ab}$ & $18.2 \mathrm{ab}$ & $21.8 \mathrm{~b}$ & $53.7 \mathrm{c}$ \\
129 & $16.8 \mathrm{a}$ & $20.2 \mathrm{ab}$ & $23.4 \mathrm{~b}$ & $24.1 \mathrm{~b}$ & - \\
140 & $17.2 \mathrm{a}$ & $20.3 \mathrm{ab}$ & $24.2 \mathrm{~b}$ & $25.7 \mathrm{~b}$ & $64.3 \mathrm{c}$ \\
154 & $16.7 \mathrm{a}$ & $20.6 \mathrm{ab}$ & $29.1 \mathrm{~b}$ & $28.8 \mathrm{~b}$ & - \\
165 & $16.1 \mathrm{a}$ & $21.0 \mathrm{ab}$ & $32.3 \mathrm{~b}$ & $30.7 \mathrm{~b}$ & $66.8 \mathrm{c}$ \\
\hline
\end{tabular}

* Means in rows with different letters are significantly different $(P \leq 0.05)$ according to the Scheffe test.

the other species were not significantly $(P<0.05)$ different until almost 117 hours ( 5 days) after initial watering. Root length differences among species became significant $(P<0.05)$ as the seedlings became older (Table 1), a finding similar to that of Dalrymple and Dwyer (1967).

The root length-time curves among species were distinctly different (Fig. 1). The root elongation rate of 'Cochise' lovegrass and alkali sacaton NM-184 decreased abruptly around 96 hours (4 days). The root elongation rate of alkali sacaton 1733 also decreased at 96 hours but the decrease was not as abrupt. The continued increase in root elongation of alkali sacaton 1733 after 96 hours, though not statistically different than the root elongation of NM-184, may partially explain why 1733 has been more successfully established than NM-184 (Cox, J.R., USDA-ARS, personal communication). Also, Briske and Wilson (1977) found that blue grama root lengths differed among accessions and suggested that accessions with the most rapid root elongation rate should be the easiest to establish. Blue panic and sideoats grama root elongation rates remained relatively constant throughout the sample period.

Sideoats grama had the longest root lengths at any measurement time. If rapid early root elongation is a prerequisite to successful establishment as reported by Tadmor and Cohen (1968), sideoats grama should be relatively easy to establish. Conversely, 'Cochise' lovegrass should be the most difficult to establish because its roots were shortest at any measurement time. However, Jordan (unpublished Bureau of Land Management Progress Reports) found in many reseeding trials in southeastern Arizona (Cochise County) that sideoats grama was very difficult to establish whereas 'Cochise' lovegrass was readily established. Jordan's findings were based on trials conducted in a $165-\mathrm{mm}$ summer precipitation zone and when subsurface soil moisture was very low. Because roots will not grow into dry soil (Hendrickson and Veihmeyer 1931), the potential for rapid root elongation of sideoats grama would not be a beneficial attribute for successful seedling establishment under the dry subsurface soil conditions. Tromble (1974), working in a 190-mm summer precipitation zone, had excellent success in establishing sideoats grama on a root-plowed site in southeastern Arizona. Tromble drill seeded sideoats grama around mid-July after previous rains had been sufficient to wet subsurface soil zones. Under conditions of wet subsurface soil, sideoats grama will rapidly extend its seminal root into zones of subsurface soil moisture and not be totally dependent on soil moisture relations of the drastically changing upper soil zones.

\section{Shoot Lengths}

Seedling shoots are sites of carbohydrate synthesis and the larger the shoot the greater the opportunity for seedling growth (Kramer, 1983). Though large shoots promote food production, they also promote high rates of transpiration which are accentuated in dry, hot climates.

Mean shoot lengths of sideoats grama were significantly $(P<0.05)$ longer than those of all other species until almost 140 hours $(6$ days), when blue panic and sideoats grama shoot lengths were not significantly $(P<0.05)$ different but were still greater than the shoot lengths of the other species (Table 2). Shoot elongation of all

Table 2. Mean shoot lengths of species for selected sample times.*

\begin{tabular}{lccccc}
\hline & Alkali & & Alkali & \\
Time (hr) & $\begin{array}{c}\text { Cochise } \\
\text { Lovegrass }\end{array}$ & $\begin{array}{c}\text { Sacaton } \\
\text { NM-184 }\end{array}$ & $\begin{array}{c}\text { Blue } \\
\text { Panic }\end{array}$ & $\begin{array}{c}\text { Sacaton } \\
1733\end{array}$ & $\begin{array}{c}\text { Sideoats } \\
\text { Grama }\end{array}$ \\
\hline & & & & & \\
58 & $1.2 \mathrm{a}$ & $2.4 \mathrm{a}$ & $3.0 \mathrm{a}$ & $1.5 \mathrm{a}$ & $9.2 \mathrm{~b}$ \\
70 & $3.2 \mathrm{a}$ & $4.1 \mathrm{a}$ & $4.5 \mathrm{a}$ & $2.7 \mathrm{a}$ & $12.1 \mathrm{~b}$ \\
80 & $6.9 \mathrm{a}$ & $6.3 \mathrm{a}$ & $6.7 \mathrm{a}$ & $5.0 \mathrm{a}$ & $16.2 \mathrm{~b}$ \\
92 & $8.4 \mathrm{a}$ & $7.8 \mathrm{a}$ & $8.9 \mathrm{a}$ & $6.7 \mathrm{a}$ & $18.5 \mathrm{~b}$ \\
105 & $9.2 \mathrm{a}$ & $10.6 \mathrm{ab}$ & $12.4 \mathrm{~b}$ & - & $18.7 \mathrm{c}$ \\
117 & $9.8 \mathrm{a}$ & $10.9 \mathrm{a}$ & $14.9 \mathrm{~b}$ & $9.9 \mathrm{a}$ & $20.6 \mathrm{c}$ \\
129 & $11.2 \mathrm{a}$ & $12.3 \mathrm{a}$ & $18.0 \mathrm{~b}$ & $11.1 \mathrm{a}$ & - \\
140 & $11.4 \mathrm{a}$ & $12.1 \mathrm{a}$ & $20.3 \mathrm{~b}$ & $12.0 \mathrm{a}$ & $24.8 \mathrm{~b}$ \\
154 & $12.5 \mathrm{a}$ & $12.3 \mathrm{a}$ & $22.7 \mathrm{~b}$ & $12.9 \mathrm{a}$ & - \\
165 & $12.1 \mathrm{a}$ & $12.2 \mathrm{a}$ & $25.0 \mathrm{~b}$ & $13.8 \mathrm{a}$ & $28.7 \mathrm{~b}$ \\
\hline
\end{tabular}

* Means in rows with different letters are significantly different $(P \leq 0.05)$ according to the Scheffe test.

species during the period of measurement lagged behind root elongation, a phenomenon found for seedlings of many plant species (Oppenheimer 1960, Wiese 1968, Evetts and Burnside 1973). Except for sideoats grama and alkali sacaton 1733, the shoot length-time curves had shapes similar to the root length-time curves (Fig. 1). Shoot elongation of sideoats grama and alkali sacaton 1733 declined much sooner than root elongation.

There was no significant $(P<0.05)$ shoot length difference between accessions of alkali sacaton, and their shoot length-time curves resemble the shoot length-time curve of 'Cochise' lovegrass. 

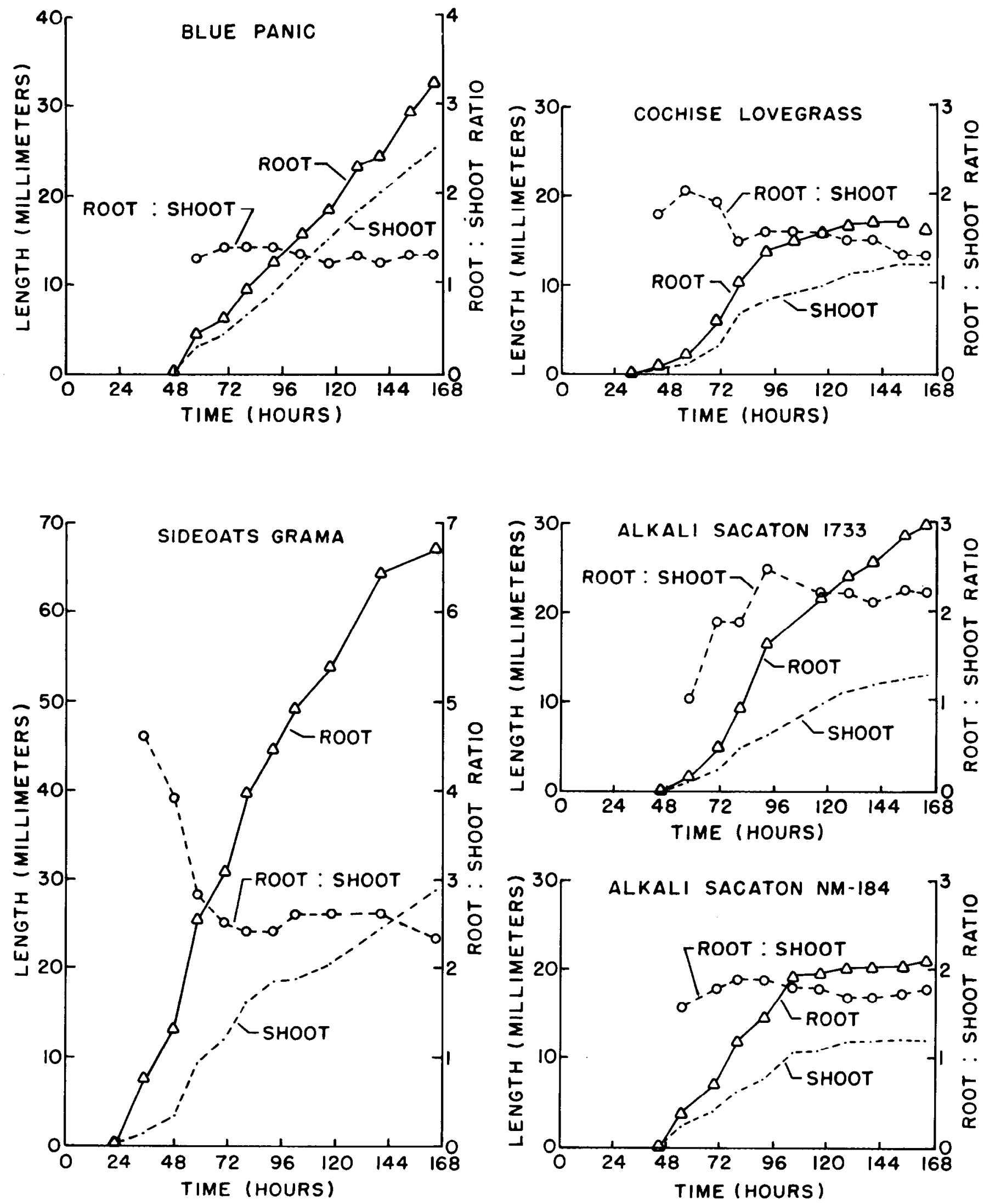

Fig. 1. Root and shoot lengths, and root:shoot ratios for various sample times of all species. 


\section{Germination}

Because of the sampling method used, there was an interaction between the germination rate of each species and the time dependent root and shoot length measurements. This interaction is important if absolute growth rates are desired; but for this study, the interest was in determination of root and shoot lengths at various times from initial watering, so separation of germination rate from root or shoot length was not made.

Curves of average cumulative germination, based on number of seeds germinated for each species, indicated 3 groupings (Fig. 2).

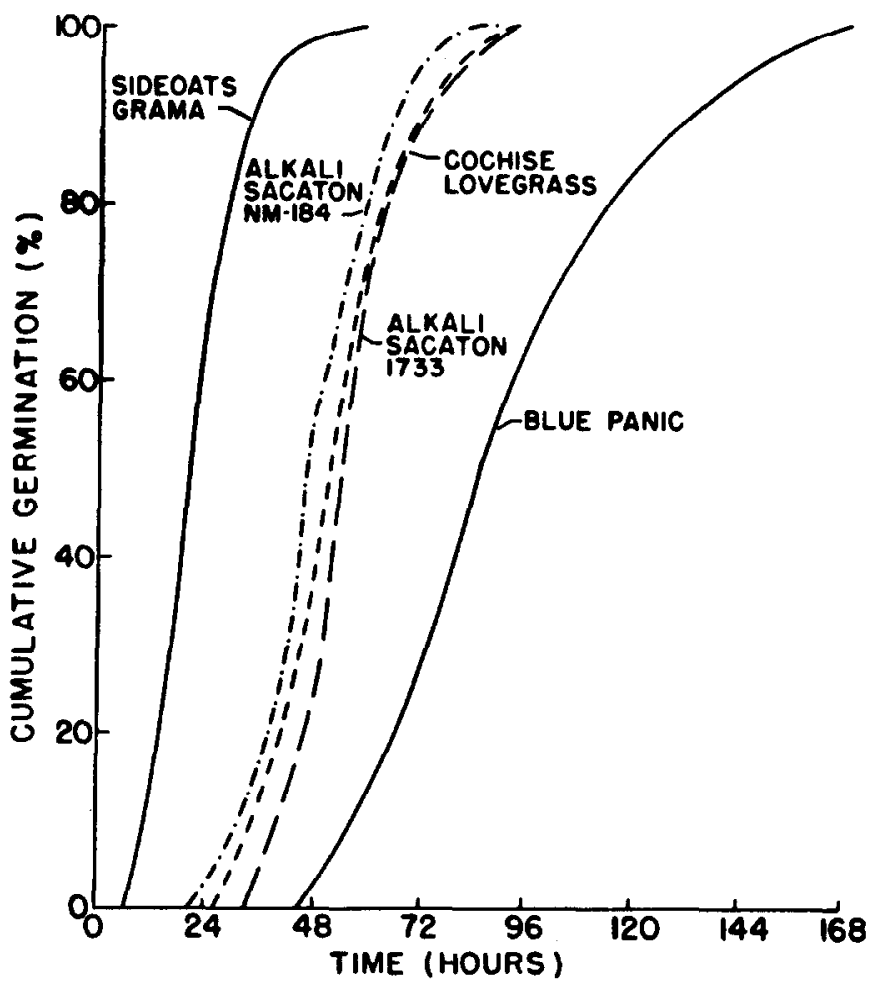

Fig. 2. Curves of cumulative germination of seeds for all species.

These 3 groupings were also separated using a germination rate index (Evetts and Burnside 1972). The index reflects the overall germination rate of a species from time of watering to final germination count and compensates for percentage of seeds germinated. The germination rate index ranged from a high of 1.0 for sideoats grama to a low of 0.3 for blue panic. 'Cochise' lovegrass and the 2 accessions of alkali sacaton had an index of 0.4 . Also, time to achieve $50 \%$ germination is commonly used to reflect rapidity of germination. The times to $50 \%$ germination of sideoats grama, alkali sacaton NM-184, 'Cochise' lovegrass, alkali sacaton 1733, and blue panic were $22,46,50,52$, and 80 hours, respectively.

Rapid germination is an important factor in the success or adaptability of a species (Whalley et al. 1966, Jordan 1981). However, in climates characterized by sporadic and often small rainfall events such as found in southeastern Arizona, rapid germination may be a detriment to a species. For example, the rapid germination of sideoats grama seed can be either a positive or negative factor in establishment, depending on the amount and temporal distribution of rainfall. Under favorable conditions, nearly all viable sideoats grama seeds would respond quickly to rainfall (Frasier et al. 1984). If the amount of rain was insufficient to adequately wet subsurface soil zones, the seeds would germinate but the rapid root growth characteristic of sideoats grama would be of little benefit because the root would grow into dry soil. Under the same conditions, a relatively smaller portion of viable 'Cochise' lovegrass seeds would respond because of their slower germination rate (Fraiser et al. 1984). If the moisture was inadequate to sustain growth, the sideoats grama and the 'Cochise' lovegrass seedlings would die, leaving a much depleted population of sideoats grama seeds compared to the slower germinating 'Cochise'lovegrass seed population. The 'Cochise'lovegrass seed population would probably persist through many wet-dry moisture cycles, thus increasing the chance of a moisture impulse of sufficient size to sustain seedling growth even though 'Cochise' lovegrass has very slow root elongation.

\section{Root:Shoot Ratios}

Root:shoot length ratios, were determined as a possible indicator of seedling drought resistance. Presumably, the larger the ratio, the more drought resistant the seedling (Oppenheimer 1960). Root:shoot ratios varied within and among species with time (Fig. 1) and the 7-day average root:shoot ratios were 2.9:1, 2.2:1, 1.8:1, 1.6:1, and 1.3:1 for sideoats grama, alkali sacaton 1733, alkali sacaton NM-184, 'Cochise' lovegrass, and blue panic, respectively.

Three time-related trends in root:shoot ratios were found among the species studied (Fig. 1). Root:shoot ratios of 'Cochise' lovegrass and alkali sacaton 1733 increased with time during the first 72 ( 3 days) to 96 hours ( 4 days) after initial watering and then decreased and became relatively constant. Blue panic and alkali sacaton NM-184 root:shoot ratios remained fairly constant throughout the evaluation period. The root:shoot ratio of sideoats grama was initially high (4.6:1) and decreased rapidly with time until about 72 hours ( 3 days) when the ratio became relatively constant (around 2.5:1). This decrease in the root:shoot ratio of older-aged sideoats grama plants also was found by Dalrymple and Dwyer (1967).

If a high root:shoot ratio is a morphological characteristic of drought resistance, as suggested by Wright and Streetman (1960), then sideoats grama should be the easiest to establish of the species studied. However, even though sideoats grama has the largest 7 -day average root:shoot ratio, this species has been difficult to establish in the semiarid climates compared to 'Cochise' lovegrass and blue panic, whose initial root:shoot ratios are less than 2:1.

\section{Conclusions}

Comparatively high root:shoot ratios, very rapid germination, and rapid seminal root elongation have been reported to be positive seedling characteristics important for establishment in semiarid or arid environments. Even though these characteristics are found in sideoats grama, range managers have had limited success with this species in reseeding programs in southeastern Arizona where there was less than $190 \mathrm{~mm}$ summer rainfall, and when subsurface soil moisture was very low. 'Cochise' lovegrass has a relatively low root:shoot ratio, slow germination rate, and the slowest seminal root elongation rate of the species studied. However, 'Cochise' lovegrass has been successfully used in reseeding programs in the semiarid Southwest. Sideoats grama and 'Cochise' lovegrass show an interesting contrast of morphological characteristics and, of the species studied, probably represent the extremes in morphological and physiological adaptations to climatic conditions, respectively.

\section{Literature Cited}

Briske, D.D., and A.M. Wilson. 1977. Temperature effects on adventitious root development in blue grama seedlings. J. Range Manage. 30:276-280.

Cox, J.R., and G.L. Jordan. 1983. Density and production of seeded range grasses in southeastern Arizona (1970-1982). J. Range Manage. 36:649-651.

Dalrymple, R.L., and D.D. Dwyer. 1967. Root and shoot growth of five range grasses. J. Range Manage. 20:141-145.

Evetts, L.L., and O.C. Burnside. 1972. Germination and seedling development of common milkweed and other species. Weed Sci. 20:371-378.

Evetts, L.L., and O.C. Burnside. 1973. Early root and shoot development of nine plant species. Weed Sci. 21:289-291.

Frasier, G.W., D.A. Woolhiser, and J.R. Cox. 1984. Emergence and seedling survival of two warm-season grasses as influenced by the timing of precipitation: A greenhouse study. J. Range Manage. 37:7-11. 
Hendrickson, A.H., and F.J. Veihmeyer. 1931. Influence of dry soil on root extension. Plant Physiol. 6:567-576.

Jordan, G.L. 1981. Range seeding and brush management on Arizona rangelands. Agr. Exp. Sta., T81121, Univ. Ariz., Tucson.

Knipe, O.D. 1967. Influence of temperature on the germination of some range grasses. J. Range Manage. 20:298-299.

Kramer, P.J. 1983. Water relations of plants. Academic Press, New York.

Mueller, I.M., and J.E. Weaver. 1942. Relative drought resistance of seedlings of dominant prairie grasses. Ecology 23:387-398.

Noy-Meir, I. 1973. Desert ecosystems:environment and producers. Ann. Rev. Ecol. Sys. 4:25-51.

Oppenheimer, H.R. 1960. Adaptation to drought: Xerophytism. In: PlantWater Relationships in Arid and Semi-Arid Conditions. UNESCO, Switzerland.

Snedecor, G.W., and W.G. Cochran. 1980. Statistical methods. Iowa State Univ. Press, Ames, Iowa.

Sosebee, R.E., and C.H. Herbel. 1969. Effects of high temperature on emergence and initial growth of range plants. Agron. J. 61:621-624.

Tadmor, N.H., and Y. Cohen. 1968. Root elongation in the preemergence stage of Mediterranean grasses and legumes. Crop Sci. 8:416-419.
Tapia, C.R., and E.M. Schmutz. 1971. Germination responses of three desert grasses to moisture stress and light. J. Range Manage. 24:292-295.

Tromble, J.M. 1974. Increasing forage production on a semiarid rangeland watershed. Hydr. and Water Resources in Ariz. and the Southwest 4:33-40.

Troughton, A. 1956. Studies on the growth of young grass plants with special reference to the relationship between the shoot and root systems. J. Brit. Grassland Soc. 11:56-65.

Whalley, R.D.B., C.M. McKell, and L.R. Green. 1966. Seedling vigor and early nonphotosynthetic stage of seedling growth in grasses. Crop Sci. 6:147-150.

Wiese, A.F. 1968. Rate of weed root elongation. Weed Sci. 16:11-13.

Wilson, A.M., and D.D. Briske. 1979. Seminal and adventitious root growth of blue grama seedlings on the Central Plains. J. Range Manage. 32:209-213.

Wilson, A.M., D.N. Hyder, and D.D. Briske. 1976. Drought resistance characteristics of blue grama seedlings. Agron. J. 68:479-484.

Wright, N., and L.J. Streetman. 1960. Grass improvement for the Southwest. Tech. Bull. 143. Agr. Exp. Sta., Univ. Arizona, Tucson. 